\title{
Molecular Profiling and Optimization Studies for Growth and PHB Production Conditions in Rhodobacter sphaeroides
}

\author{
Yu Rim Lee ${ }^{1,2,+} \oplus$, Hana Nur Fitriana ${ }^{1,3, \dagger}$, Soo Youn Lee ${ }^{1,+}$, Min-Sik Kim ${ }^{4}$, Myounghoon Moon ${ }^{1}$, \\ Won-Heong Lee ${ }^{5}$, Jin-Suk Lee ${ }^{1}$ and Sangmin Lee ${ }^{1, *}$ \\ 1 Gwangju Bio/Energy R\&D Center, Korea Institute of Energy Research, Gwangju 61003, Korea; \\ rimin9@kier.re.kr (Y.R.L.); hana3004ap@gmail.com (H.N.F.); syl@kier.re.kr (S.Y.L.); mmoon@kier.re.kr (M.M.); \\ bmjslee@kier.re.kr (J.-S.L.) \\ 2 Interdisciplinary Program of Agriculture and Life Sciences, Chonnam National University, Gwangju 61186, Korea \\ 3 Renewable Energy Engineering Department, Korea Institute of Energy Research Campus, University of \\ Science and Technology, Daejeon 34113, Korea \\ 4 Energy Resources Upcycling Research Laboratory, Korea Institute of Energy Research, Daejeon 34129, Korea; \\ kms0540@kier.re.kr \\ 5 Department of Integrative Food, Bioscience and Biotechnology, Chonnam National University, \\ Gwangju 61186, Korea; wonhlee@jnu.ac.kr \\ * Correspondence: silverlsm@kier.re.kr; Tel.: +82-62-717-2425 \\ + These authors contributed equally to this work.
}

Received: 21 October 2020; Accepted: 25 November 2020; Published: 7 December 2020

\begin{abstract}
In the recent climate change regime, industrial demand for renewable materials to replace petroleum-derived polymers continues to rise. Of particular interest is polyhydroxybutyrate (PHB) as a substitute for polypropylene. Accumulating evidence indicates that PHB is highly produced as a carbon storage material in various microorganisms. The effects of growth conditions on PHB production have been widely studied in chemolithotrophs, particularly in Rhodobacter. However, the results on PHB production in Rhodobacter have been somewhat inconsistent due to different strains and experimental conditions, and it is currently unclear how diverse environmental factors are linked with PHB production. Here, we report optimized growth conditions for PHB production and show that the growth conditions are closely related to reactive oxygen species (ROS) regulation. PHB accumulates in cells up to approximately $50 \%$ at the highest level under dark-aerobic conditions as opposed to light aerobic/anaerobic conditions. According to the time-course, $\mathrm{PHB}$ contents increased at $48 \mathrm{~h}$ and then gradually decreased. When observing the effect of temperature and medium composition on PHB production, $30^{\circ} \mathrm{C}$ and a carbon/nitrogen ratio of 9:1 or more were found to be most effective. Among PHB biosynthetic genes, PhaA and PhaB are highly correlated with PHB production, whereas $\mathrm{PhaC}$ and $\mathrm{PhaZ}$ showed little change in overall expression levels. We found that, while the amount of hydrogen peroxide in cells under dark conditions was relatively low compared to the light conditions, peroxidase activities and expression levels of antioxidant-related genes were high. These observations suggest optimal culture conditions for growth and PHB production and the importance of ROS-scavenging signaling with regard to PHB production.
\end{abstract}

Keywords: Rhodobacter; polyhydroxybutyrate; growth conditions; reactive oxygen species

\section{Introduction}

Biopolymers are very important materials in responding to environmental pollution and global warming, and their production is increasing. Among them, polyhydroxyalkanoate (PHA), which is used 
as a representative biopolymer, is a highly interesting and useful biochemical, because it can replace petrochemicals such as polypropylene [1]. In particular, poly- $\beta$-hydroxybutyrate (PHB), one the PHAs, has been the most widely studied product and has already reached a level of commercialization [2]. However, in order to compete with petrochemicals, there is a need to dramatically improve the economic feasibility, especially in the feed supply.

PHB is known as a bacterial energy storage material that accumulates in cells under a carbon-rich environment [3,4]. It is biosynthesized in three steps from acetyl-CoA in most microorganisms. Two molecules of acetyl-CoA are condensed to an acetoacetyl-CoA by acetyl-CoA acetyltransferase (PhaA) and then reduced to $\beta$-hydroxybutyryl-CoA by acetoacetyl-CoA reductase (PhaB). Lastly, PHB synthase $(\mathrm{PhaC})$ catalyzes polymerization to PHB [5,6]. PHB depolymerase, encoded by PhaZ, hydrolyzes PHB to utilize it as a carbon and energy source under energy starving conditions [7].

PHA production has been studied in diverse microorganisms such as Escherichia coli and Pseudomonas species, under various conditions [8-11]. Recombinant E. coli harboring PHB synthesizing genes from Streptomyces aureofaciens showed different PHB accumulation according to the medium composition including amino acid sments, carbon source, and nitrogen source $[8,9]$. Smentation of amino acids except glycine and valine enhance PHB accumulation, and the maximum PHB content ( $60 \%$ of dry cell weight) was accomplished in a medium with glycerol as the sole carbon source, and yeast extract and peptone as the nitrogen source [9]. In Pseudomonas species, medium-chain length PHAs were produced from sludge palm oil or vegetable oil under a phosphate and nitrogen limited medium, suggesting that waste carbon resources can be used to reduce feed costs of PHB production $[10,11]$.

The chemotrophs, such as Ralstonia, Rhodospirillum, and Rhodobacter, have many advantages in producing biochemicals. These microorganisms contribute to reducing global warming and environmental pollution, because they utilize carbon dioxide as well as organic wastes [12-17]. Optimization of the nutrient composition in the medium for PHB production in Ralstonia eutropha has been reported [12]. When Ralstonia eutropha was grown in a medium that contains urea and corn steep liquor instead of ammonium sulphate and yeast extract, PHB contents of up to $45.1 \%$ was observed in the cells, indicating that medium conditions are critical to increase the productivity and price competitiveness of PHB.

Notably, Rhodobacter sphaeroides is a highly favorable microorganism for PHB production. Under nitrogen-limiting conditions, PHB accumulated up to $70 \%$ of cellular dry weight in $R$. sphaeroides [16]. Among various carbon sources, acetate yielded the highest PHB production [17]. Moreover, PHB productivity can be greatly improved within $R$. sphaeroides, since it is possible to enhance the performance of strains using well-established genetic engineering tools and by integrating advances in previous studies [5,18-20].

The versatile metabolism of $R$. sphaeroides is very useful for research on intracellular processes including photosynthesis, respiration, and various signaling networks in bacteria [21,22]. There have also been many reports on oxidative stress signaling in $R$. sphaeroides. In the microbial cells, oxidative stress is mainly caused by reactive oxygen species (ROS), which are generated from diverse cellular processes and environmental factors such as light, oxygen, and temperature [23-26]. ROS scavenging mechanisms have been evolutionally developed to combat oxidative stress, which leads to severe cellular damage in R. sphaeroides. Glutathione peroxidase, catalase, and superoxide dismutase, which remove ROS such as superoxide and hydrogen peroxide, have been identified in Rhodobacter, and the effects of antioxidants such as carotenoids and ascorbate have also been verified [27-30]. A hydrogen peroxide-inducible transcriptional activator, $\mathrm{OxyR}$, has been studied as the main regulator of ROS signaling, and a homolog of E. coli OxyR exists in R. sphaeroides [31]. The OxyR-defective oxyR mutants were more sensitive to hydrogen peroxide compared with the hydrogen peroxide sensitivity of the wild-type strain of $R$. sphaeroides, indicating that $R$. sphaeroides OxyR also has a similar function with E. coli OxyR in the oxidative stress response [31].

In this work, we investigated cell growth and PHB production under varied conditions in $R$. sphaeroides, such as light, aeration, incubation time, and temperature. We also found that PHB-biosynthetic genes, 
$P h a A$ and $P h a B$, are critical for PHB production according to environmental change, and accumulation of ROS and carotenoids changed depending on PHB production. Our observations provide optimized growth conditions for PHB production and demonstrate the close relationship between ROS metabolism and PHB production.

\section{Materials and Methods}

\subsection{Bacterial Strain and Growth Conditions}

Rhodobacter sphaeroides KCTC1434 strain was purchased from Korean Collection for Type Cultures (KCTC) and grown on Sistrom's minimal medium [32]. The cells were cultured at $30^{\circ} \mathrm{C}$ and $150 \mathrm{rpm}$ under aerobic-dark conditions. The growth of cells was monitored by measuring optical density (OD) using a spectrophotometer (Mega-800, Scinco, Seoul, Korea) at $660 \mathrm{~nm}$, with sufficient dilution of the culture broth. The values of optical density were calculated to dry cell weight using our standard curve of cell mass for $\mathrm{OD}_{660}\left(\mathrm{OD}_{660} 1=0.5678 \mathrm{~g} / \mathrm{L}\right)$.

To examine the effects of light, oxygen, temperature, and $\mathrm{C} / \mathrm{N}$ ratio on cell growth and PHB production, the precultured cells were added to $100 \mathrm{~mL}$ of Sistrom's medium in $250 \mathrm{~mL}$ Erlenmeyer flasks after being diluted to an $\mathrm{OD}_{660}$ of 0.1 and cultured under various growth conditions for $48 \mathrm{~h}$. For anaerobic experiments, all serum bottles were purged with argon gas.

\subsection{PHB Extraction and Analysis}

For the PHB analysis, approximately $10 \mathrm{mg}$ of lyophilized whole cells was reacted in a small screw-cap test tube with a $2 \mathrm{~mL}$ solution containing $85 \%(v / v)$ methanol, $15 \%(v / v)$ concentrated sulfuric acid, and $250 \mathrm{mg} / \mathrm{L}$ benzoic acid as an internal standard. After addition of $2 \mathrm{~mL}$ chloroform, the mixture was incubated for $3.5 \mathrm{~h}$ in a heating block at $100{ }^{\circ} \mathrm{C}$. The tubes were cooled to room temperature. After addition of $1 \mathrm{~mL}$ of $1 \mathrm{M} \mathrm{NaCl}$ to each tube, the mixtures were shaken for $1 \mathrm{~min}$ and centrifuged at $4200 \mathrm{rpm}$ for $10 \mathrm{~min}$. The bottom organic layer containing PHB was dried over sodium sulfate before analysis. The organic phase was analyzed by a gas chromatograph (7890, Agilent, Santa Clara, CA, USA) equipped with a flame ionization detector (FID). The capillary column was a HP-5 from Agilent J \& W Scientific, $30 \mathrm{~m}$ in length with $0.25 \mathrm{~mm}$ internal diameter. The injection split ratio was 60:1. The injection port and the detector temperatures were 180 and $200^{\circ} \mathrm{C}$, respectively. The initial oven temperature was maintained for one minute at $90{ }^{\circ} \mathrm{C}$ with an increase of $8{ }^{\circ} \mathrm{C} / \mathrm{min}$ to a final temperature of $150{ }^{\circ} \mathrm{C}$ maintained for five minutes. The flow rate of the helium carrier gas was $1 \mathrm{~mL} / \mathrm{min}$. The PHB polymer (363502, Sigma-Aldrich, St. Louis, MO, USA) was used as an external standard.

\subsection{HPLC Analysis for Organic Acids}

The organic acids from the cell culture were analyzed by an HPLC (1260, Agilent, Santa Clara, CA, USA) equipped with a UV detector. The samples were centrifuged, and the supernatants were collected and filtered through $0.2 \mu \mathrm{m}$ pore size membrane syringe filter. The capillary column was an Aminex ${ }^{\circledR} \mathrm{HPX}-87 \mathrm{H}, 300 \mathrm{~mm}$ in length with $7.8 \mathrm{~mm}$ internal diameter. The separation was achieved isocratically, using a mobile phase of $5 \mathrm{mM}$ sulfuric acid pumped at a flow rate $0.6 \mathrm{~mL} / \mathrm{min}$ at $50{ }^{\circ} \mathrm{C}$. The injection volume was $20 \mu \mathrm{L}$, and the detection was made at $210 \mathrm{~nm}$. Succinic acid and fumaric acid were used as organic acid standards.

\subsection{RNA Isolation and Transcript Analysis by $q R T-P C R$}

To analyze the transcript levels of PHB biosynthetic genes and ROS-related genes, total RNA samples were isolated from the harvested cells using a Quick-RNA Fungal/Bacterial Miniprep kit (Zymo Research, Irvine, CA, USA). RNase-free DNaseI was treated to total RNA samples to remove any contaminating genomic DNA. The cDNA was synthesized by using a GoScript Reverse Transcription System (Promega, Madison, WI, USA). qRT-PCR was performed in 96-well blocks with QuantStudio 6 Flex (Applied Biosystems, Foster City, CA, USA) using the SYBR Green I master mix. The parameter 
is one cycle of $95^{\circ} \mathrm{C}$ for $20 \mathrm{~s}$ followed by 40 cycles of $95{ }^{\circ} \mathrm{C}$ for $1 \mathrm{~s}, 60^{\circ} \mathrm{C}$ for $20 \mathrm{~s}$. RpoZ gene, encoding DNA-directed RNA polymerase $\omega$-subunit, was designated as the endogenous reference gene for normalizing RNA levels. Relative expression of genes was analyzed using the comparative Ct method, as described previously [33].

\subsection{Determination of $\mathrm{H}_{2} \mathrm{O}_{2}$ Concentration and Peroxidase Activity}

The endogenous levels of hydrogen peroxide $\left(\mathrm{H}_{2} \mathrm{O}_{2}\right)$ concentration and peroxidase activities were measured using an Amplex ${ }^{\circledR}$ Red Hydrogen Peroxide/Peroxidase Assay Kit (Molecular Probes, Eugene, OR, USA), as described previously [34]. Briefly, cell lysis was carried out by sonication, and samples were prepared in potassium phosphate buffer ( $\mathrm{pH}$ 7.5). Fifty microliters of sample was mixed with the reaction reagent, including the Amplex Red reagent (10-acetyl-3,7-dihydroxyphenoxazine) and horseradish peroxidase (HRP) and incubated for $30 \mathrm{~min}$ according to the manufacturer's protocol. For measurement of peroxidase activities, $\mathrm{H}_{2} \mathrm{O}_{2}$ should be added instead of HRP. Fluorescence was read at excitation/emission of $530 \mathrm{~nm} / 590 \mathrm{~nm}$. Intracellular $\mathrm{H}_{2} \mathrm{O}_{2}$ levels were quantified using the $\mathrm{H}_{2} \mathrm{O}_{2}$ standard curve, and peroxidase activities were assessed using the horseradish peroxidase (HRP) standard curve. Fluorescence measurements were carried out using a SYNERGY H1 microplate reader (BioTek, Winooski, VT, USA).

\subsection{Total Carotenoids Extraction}

To extract total carotenoids from R. sphaeroides, $33.3 \mathrm{mg}$ of freeze-dried cells were soaked in $1 \mathrm{~mL}$ of $3 \mathrm{M} \mathrm{HCl}$ and incubated for $30 \mathrm{~min}$ in a shaking incubator at $30^{\circ} \mathrm{C}, 100 \mathrm{rpm}$. The suspensions were centrifuged at 10,000 rpm for $20 \mathrm{~min}$, and the supernatants were discarded. One milliliter of acetone was added to the pellet, which was put in the shaking incubator for $30 \mathrm{~min}$. Afterwards, the suspension was centrifuged for $20 \mathrm{~min}$, and the supernatants were transferred to new tubes. The supernatant should be sufficiently diluted depending on the sample. One hundred microliters of sample was moved into 96-well microplate, and the absorbance was read at $480 \mathrm{~nm}$.

\subsection{Statistical Analysis}

All statistical significance of the measurements was determined using a Student $t$-test. The data were expressed as mean \pm standard deviation. A $p$ value of less than 0.05 was considered statistically significant.

\section{Results}

\subsection{Effects of Light and Aeration on PHB Production}

The purple non-sulfur bacterium Rhodobacter sphaeroides grows under both phototrophic and chemolithotrophic conditions and utilizes a wide range of substrates, including carbon dioxide, succinic acid, and acetic acid $[16,35,36]$. Although many studies have been conducted on the production of PHB under various growth conditions in $R$. sphaeroides, varying results on how each environmental factor affects cell growth and PHB production have been obtained because of differences in genotypes and experimental conditions [16,17,37-39].

We set up four different growth conditions, light-aerobic, dark-aerobic, light-anaerobic, and dark-anaerobic, to elucidate the effects of light and aeration on cell growth and PHB production. Whereas cell growth and PHB contents were much higher in the dark than in the light under aerobic conditions, they were only measured in the light because cells did not grow in the dark under anaerobic conditions (Figure 1A). In anaerobic fermentation, the light is essential to photosynthesis and anaerobic respiration for the cells [40]. Consistent with the results of cell growth and PHB accumulation, succinic acid was most highly consumed under dark-aerobic conditions (Figure 1B). The concentration of fumaric acid, an intermediate of succinic acid metabolism in the TCA cycle, was higher in the light than in the dark under aerobic conditions, indicating that succinic acid metabolism slightly differs between the light and dark conditions. 
A

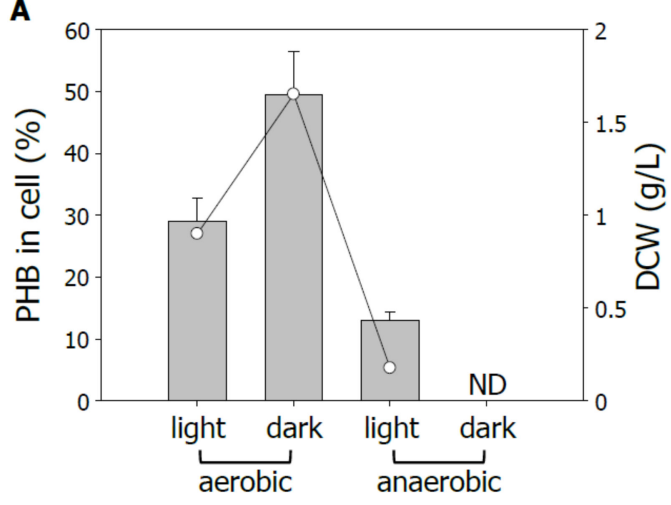

c
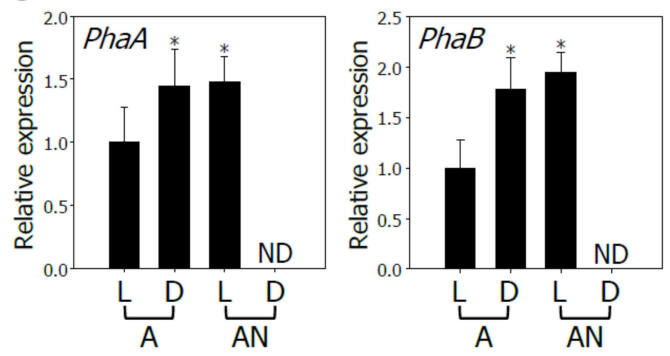
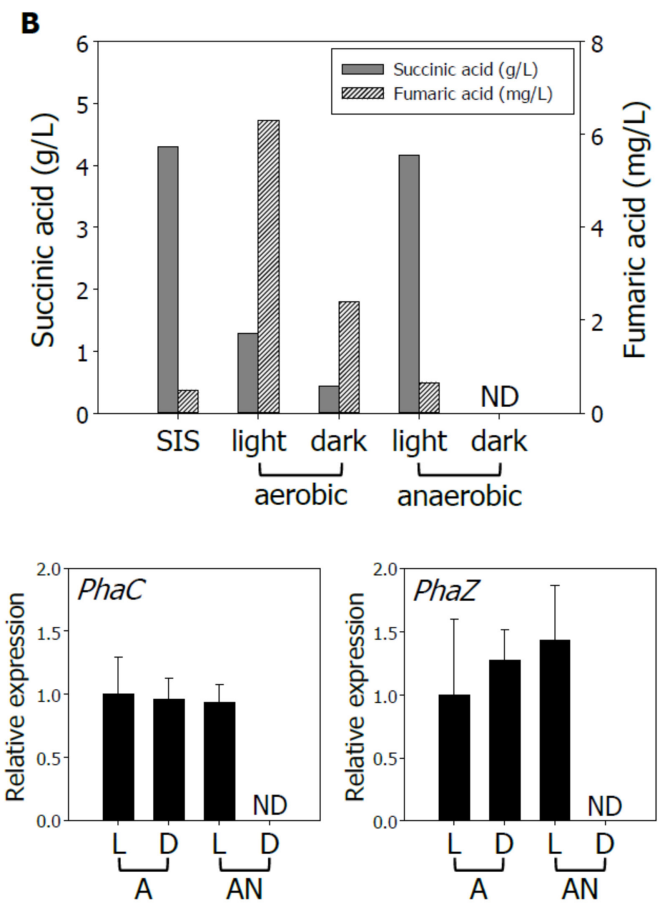

Figure 1. Effects of light and aeration on polyhydroxybutyrate (PHB) production in R. sphaeroides. (A) PHB accumulation (\% of dry cell weight) and cell growth. The samples were harvested at $48 \mathrm{~h}$ after inoculation. Gray bars for PHB contents and open circle lines for dry cell weight (DCW). (B) Measurement of organic acids concentrations. SIS, Sistrom's medium. (C) Expression of genes encoding PHB biosynthetic enzymes. PhaA, acetyl-CoA acetyltransferase (RSP_0745); PhaB, acetoacetyl-CoA reductase (RSP_0747); PhaC, PHB polymerase (RSP_0382); PhaZ, PHB depolymerase (RSP_0383). L, light; D, dark; A, aerobic; $\mathrm{AN}$, anaerobic. Experiments were performed in triplicate and bars indicate standard error of the mean. Asterisks represent a statistically significant difference, as determined by a Student $t$-test $\left({ }^{*} p<0.05\right)$. ND is not determined.

Based on these observations, we next examined expression of PHB biosynthetic genes under light/dark and aerobic/anaerobic conditions. The PhaA, encoding acetyl-CoA acetyltransferase, and $P h a B$, encoding acetoacetyl-CoA reductase, genes were slightly induced more than 1.5-fold under dark-aerobic and light-anaerobic conditions. However, the PhaC, encoding PHB polymerase, and PhaZ, encoding PHB depolymerase, genes were expressed almost consistently under all conditions except for dark-anaerobic (Figure 1C). Together, these results suggest that dark-aerobic is optimal conditions for cell growth and PHB production.

\subsection{PHB Production According to Time-Course}

Depending on the growth stage, intracellular metabolism is dramatically different [41]. To confirm the change in PHB production according to time-course, we analyzed cell growth and PHB contents under dark-aerobic conditions where PHB accumulation was the highest. The cells were cultured at $30^{\circ} \mathrm{C}$ and harvested at $24,48,72$, and $96 \mathrm{~h}$ for analysis.

The dry cell weight reached its maximum in $48 \mathrm{~h}$ and then decreased. Likewise, the PHB content was the highest at $49.45 \%$ of dry cell weight in $48 \mathrm{~h}$ and continued to decrease (Figure 2A). After $48 \mathrm{~h}$, it is considered that the cell vitality have decreased, and their PHB content dropped by almost $50 \%$ compared to $48 \mathrm{~h}$. Succinic acid, the main carbon source in the medium, was almost totally consumed in $R$. sphaeroides after $48 \mathrm{~h}$. The initial succinic acid concentration of approximately $4 \mathrm{~g} / \mathrm{L}$ reduced to $0.6 \mathrm{~g} / \mathrm{L}$ at $48 \mathrm{~h}$ and remained constant thereafter. In contrast, the concentration of fumaric acid continued to increase reaching $8.4 \mathrm{mg} / \mathrm{L}$ at $96 \mathrm{~h}$ (Figure 2B). These observations suggest that PHB 
accumulates significantly in the early stage of cell growth in $R$. sphaeroides, and when the carbon source is depleted in the medium, PHB begins to decline.

A

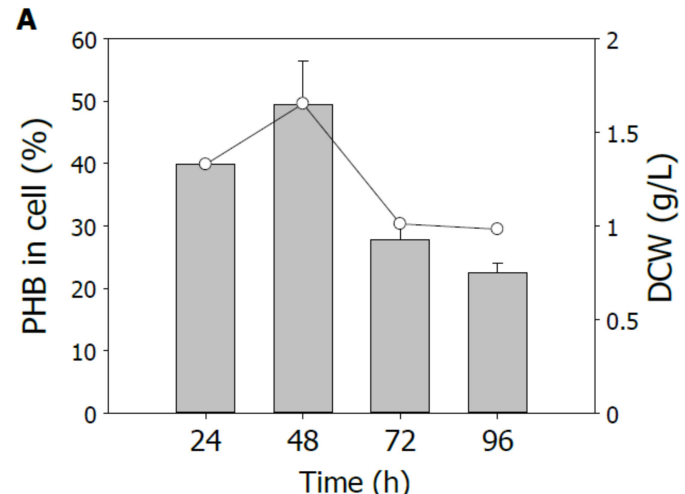

C

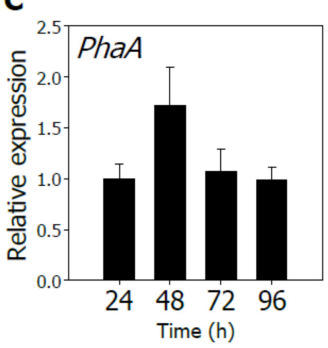

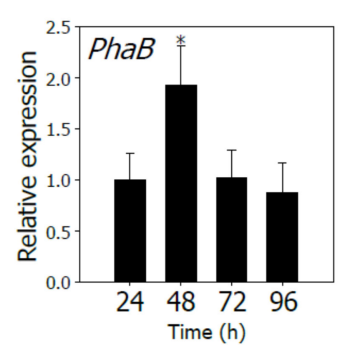

B
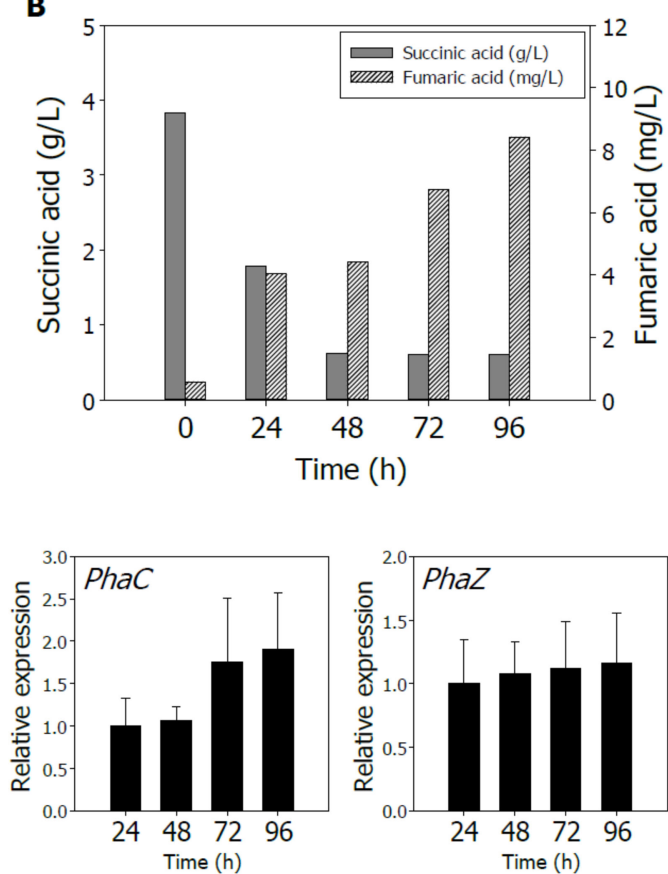

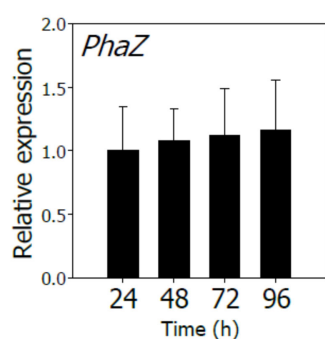

Figure 2. Growth stage-dependent PHB production in R. sphaeroides. (A) PHB accumulation (\% of dry cell weight) and cell growth. The cells were grown under dark-aerobic conditions and harvested at the indicated time points. Gray bars for PHB contents and open circle lines for DCW. (B) Measurement of organic acids concentrations. (C) Expression of genes encoding PHB biosynthetic enzymes. Experiments were performed in triplicate and bars indicate standard error of the mean. Asterisks represent statistically significant difference, as determined by a Student $t$-test $\left({ }^{*} p<0.05\right)$.

To further investigate the link between PHB biosynthesis and time-course, we analyzed transcript levels of PHB biosynthetic genes according to the culturing time. The expression of $P h a A$ and PhaB genes was, respectively, found to be higher at $48 \mathrm{~h}$ than at $24 \mathrm{~h}$, after which they decreased. In the case of the PhaC gene, expression levels were slightly higher at 72 and $96 \mathrm{~h}$ than at 24 and $48 \mathrm{~h}$. The expression of the PhaZ gene expression revealed insignificant differences in all samples (Figure 2C). It is therefore evident that the PhaA and PhaB genes among PHB biosynthetic genes are strongly correlated to the $\mathrm{PHB}$ accumulation according to time-course in R. sphaeroides.

\subsection{Effects of Temperature on PHB Production}

PHB production is highly dependent on the temperature conditions in $R$. sphaeroides, as previously reported [39]. We next examined the effects of various temperature conditions on cell growth and PHB accumulation. In the previous results, cell growth and PHB production were highest at $48 \mathrm{~h}$, so even though the growth rate was different for each temperature, the $R$. sphaeroides cells were cultivated for $48 \mathrm{~h}$ at $20,25,30,35$, and $40^{\circ} \mathrm{C}$ under aerobic conditions in darkness.

The results showed that $\mathrm{PHB}$ contents at each temperature among 20 to $40^{\circ} \mathrm{C}$ were $18.25,25.02$, $49.45,23.96$, and $21.55 \%$, respectively (Figure $3 \mathrm{~A}$ ). The change in cell growth also showed similar patterns to the PHB production. These findings support that $30^{\circ} \mathrm{C}$, known as the general R. sphaeroides growth temperature, is the optimal temperature condition for cell growth and PHB production, and they are critically inhibited at higher or lower temperatures than at $30^{\circ} \mathrm{C}$. 
A

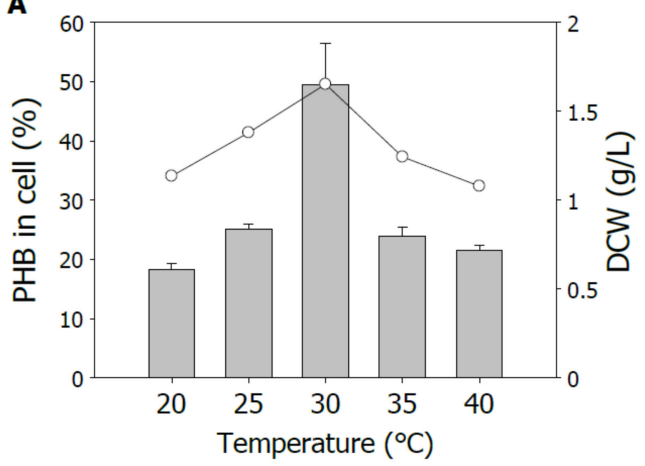

C
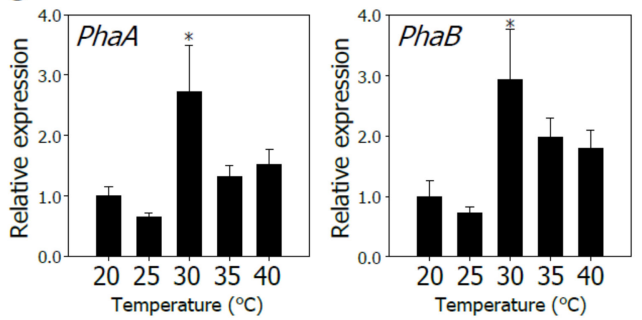
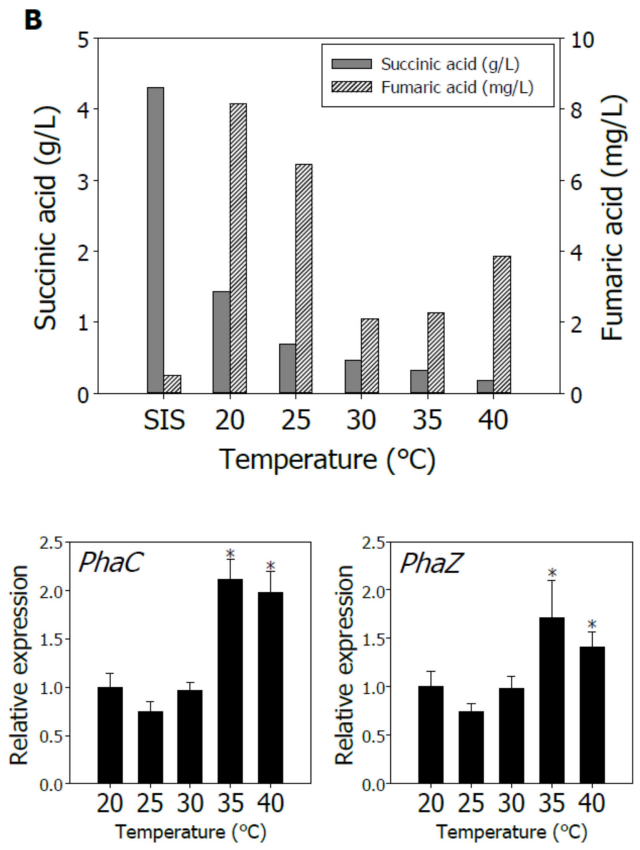

Figure 3. Effects of temperature on PHB production in R. sphaeroides. (A) PHB accumulation (\% of dry cell weight) and cell growth at different temperatures. The cells were grown under dark-aerobic conditions and harvested at $48 \mathrm{~h}$ after inoculation. Gray bars for PHB contents and open circle lines for DCW. (B) Measurement of organic acids concentrations. (C) Expression of genes encoding PHB biosynthetic enzymes. Experiments were performed in triplicate and bars indicate standard error of the mean. Asterisks represent statistically significant difference, as determined by a Student $t$-test $(* p<0.05)$.

An organic acid analysis using high-performance liquid chromatography (HPLC) revealed that all samples except those grown at $20^{\circ} \mathrm{C}$ consumed almost all succinic acid during cultivation under various temperature conditions (Figure 3B). At $20^{\circ} \mathrm{C}, 1.43 \mathrm{~g} / \mathrm{L}$ of succinic acid remained and $8.14 \mathrm{mg} / \mathrm{L}$ of fumaric acid was produced in $R$. sphaeroides. The lowest concentration of fumaric acid was measured to be $2.09 \mathrm{mg} / \mathrm{L}$ at $30^{\circ} \mathrm{C}$. Our results indicated that succinic acid metabolism is very different depending on the temperature.

Gene expression assay by quantitative real-time RT-PCR (qRT-PCR) showed that the PhaA and PhaB genes were strongly induced approximately three-fold at $30^{\circ} \mathrm{C}$ (Figure $3 \mathrm{C}$ ). Meanwhile, the transcript levels of $\mathrm{PhaC}$ and $\mathrm{PhaZ}$ genes were higher at high temperature including $35^{\circ} \mathrm{C}$ and $40^{\circ} \mathrm{C}$ compared with low temperature, indicating that the $\mathrm{PhaC}$ and $\mathrm{PhaZ}$ genes are involved in different signaling from PHB production at a high temperature.

\subsection{Effects of C/N Ratio in Growth Medium on PHB Production}

It is known that PHB is highly accumulated in an environment where the nitrogen source is insufficient and the carbon source is rich under aerobic conditions [3,4]. We therefore decided to examine the effects of the carbon to nitrogen ratio in the medium on PHB production in R. sphaeroides.

To determine the optimal $\mathrm{C} / \mathrm{N}$ ratio in the medium for $\mathrm{PHB}$ production, we prepared media with carbon to nitrogen ratios of 3:1, 6:1, 9:1, 12:1, and 15:1 using succinic acid and ammonium chloride as carbon and nitrogen sources, respectively. The $\mathrm{C} / \mathrm{N}$ ratio was altered by maintaining the carbon content at a constant level and adjusting the nitrogen content. The cells were harvested at $48 \mathrm{~h}$ under dark-aerobic conditions, as before. PHB content was highest at $51.57 \%$ at the C/N ratio of $15: 1$ and, overall, was high when the $\mathrm{C} / \mathrm{N}$ ratio was greater than 9:1 (Figure $4 \mathrm{~A}$ ). On the other hand, the cell growth was the highest at the $\mathrm{C} / \mathrm{N}$ ratio of 3:1 as opposed to $\mathrm{PHB}$ content, and biomass tended to increase as the $\mathrm{C} / \mathrm{N}$ ratio decreased. The organic acids in the medium, including succinic acid and fumaric 
acid, were not detected at $\mathrm{C} / \mathrm{N}$ ratios of 3:1 and 6:1. Whereas the rate of succinic acid consumption was slower with a higher $\mathrm{C} / \mathrm{N}$ ratio, fumaric acid content was higher (Figure $4 \mathrm{~B}$ ). These observations suggest that nitrogen-rich conditions enhance cell growth and carbon-rich conditions cause PHB accumulation under aerobic conditions in $R$. sphaeroides.
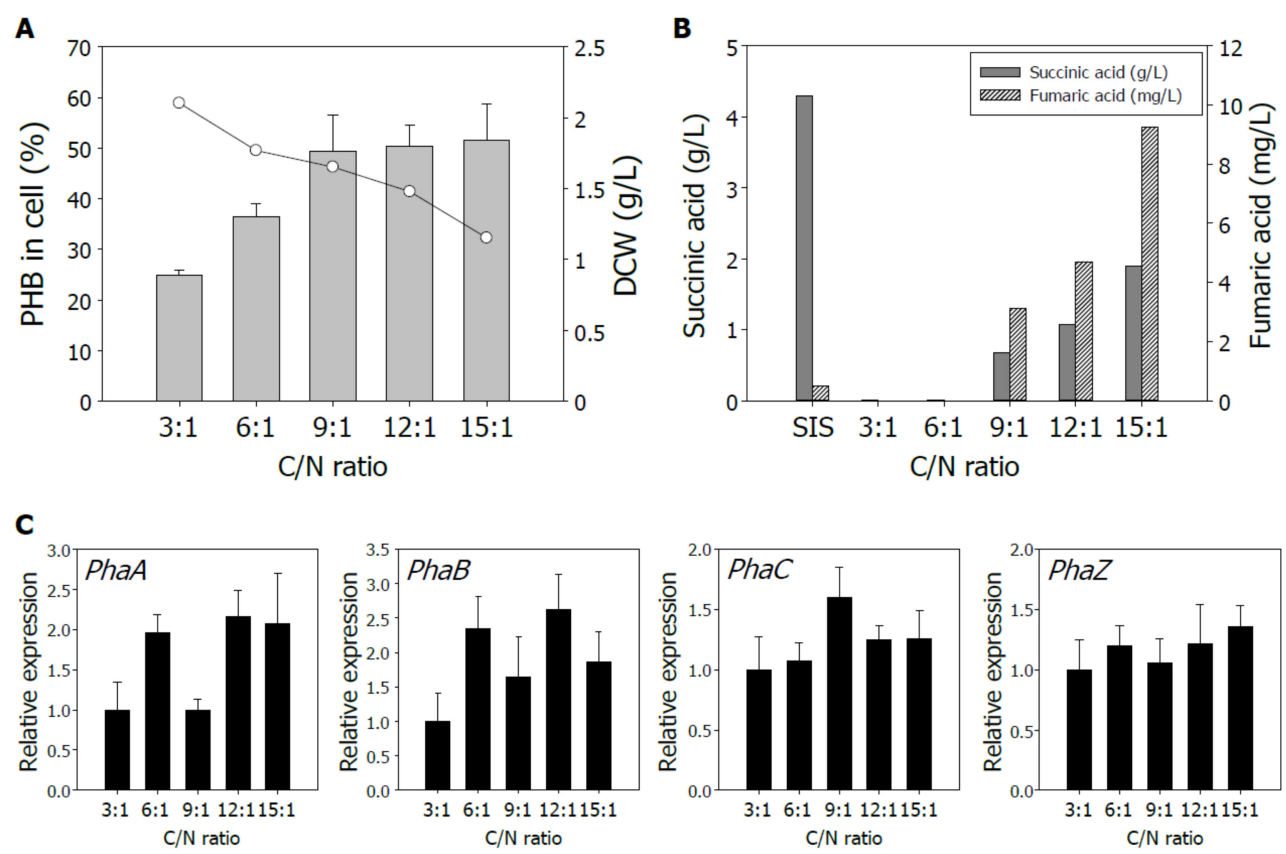

Figure 4. Effects of carbon to nitrogen ratio on PHB production in R. sphaeroides. (A) PHB accumulation (\% of dry cell weight) and cell growth under indicated $C / N$ ratio. The cells were grown under dark-aerobic conditions and harvested at $48 \mathrm{~h}$ after inoculation. Gray bars for PHB contents and open circle lines for DCW. (B) Measurement of organic acids concentrations. (C) Expression of genes encoding PHB biosynthetic enzymes. Experiments were performed in triplicate and bars indicate standard error of the mean. Asterisks represent statistically significant difference, as determined by a Student $t$-test.

Unlike the previous high correlation between PHB production and the expression of PHB biosynthetic genes, there were no distinct expression patterns depending on the $\mathrm{C} / \mathrm{N}$ ratio in the medium. Whereas the transcript levels of PhaA and PhaB genes were slightly higher at the C/N ratio of 6:1, 12:1, and 15:1, those of $P h a C$ gene were a little higher in the $\mathrm{C} / \mathrm{N}$ ratio of 9:1 (Figure $4 \mathrm{C}$ ). The PhaZ gene was constantly expressed regardless of the $\mathrm{C} / \mathrm{N}$ ratio. The previous and the present results indicated that $P h a A$ and PhaB genes have similar expression patterns, because they are located within the same operon [19]. In addition, the expression patterns of these genes showed a high correlation with PHB production except for changes in the $\mathrm{C} / \mathrm{N}$ ratio in the medium, suggesting that PHB biosynthesis is mainly regulated via PhaA and PhaB genes under various growth conditions in $R$. sphaeroides.

\subsection{ROS Regulation in R. sphaeroides}

ROS are rapidly generated in the cells depending on the levels of light and oxygen, growth stage, and temperature change [26,42-44]. Although ROS mediates adaptative responses to environmental change, high levels of ROS cause oxidative stress such as degradation of proteins and lipid peroxidation [24,25]. Considering the high correlation between light and ROS generation, we hypothesized that the differences between light and dark conditions led to changes in levels of ROS, which affected cell growth and PHB production.

To examine this hypothesis, we measured endogenous $\mathrm{H}_{2} \mathrm{O}_{2}$ contents and peroxidase activity under light and dark conditions in $R$. sphaeroides. As expected, the levels of $\mathrm{H}_{2} \mathrm{O}_{2}$ were higher 
under light conditions than under dark conditions (Figure 5A). In contrast, the activity of peroxidase, which scavenges $\mathrm{H}_{2} \mathrm{O}_{2}$, was higher under dark conditions (Figure $5 \mathrm{~B}$ ), confirming that the light causes a change in the ROS levels in $R$. sphaeroides.

A

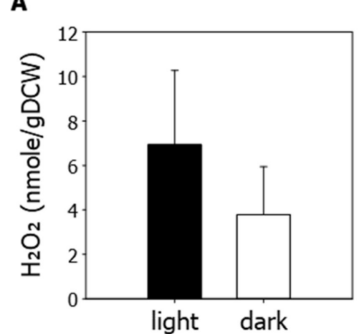

B

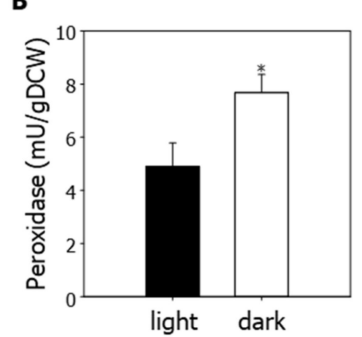

C

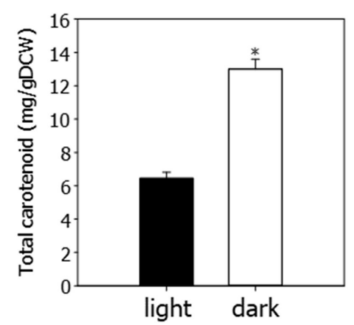

D
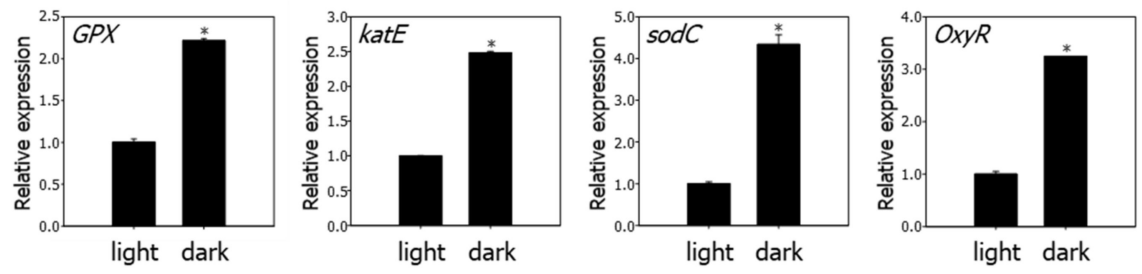

Figure 5. Regulation of endogenous reactive oxygen species in $R$. sphaeroides. Samples were harvested at $48 \mathrm{~h}$ after inoculation. (A) The endogenous levels of hydrogen peroxide $\left(\mathrm{H}_{2} \mathrm{O}_{2}\right)$ under light or dark aerobic conditions. (B) Measurement of peroxidase activity. (C) Measurement of total carotenoid contents. (D) Expression of reactive oxygen species (ROS)-related genes. GPX, glutathione peroxidase (RPS_2389); katE, catalase (RSP_2779); sodC, superoxide dismutase (RSP_1796); OxyR, hydrogen peroxide-inducible genes activator (RSP_2780). Experiments were performed in triplicate, and bars indicate standard error of the mean. Asterisks represent a statistically significant difference, as determined by a Student $t$-test $\left({ }^{*} p<0.05\right)$.

We next measured the contents of carotenoids under light and dark conditions in $R$. sphaeroides. Carotenoids, which are highly accumulated in R. sphaeroides, are known to function as an antioxidant as well as pigments [27]. Measurement of carotenoid levels showed that the contents of carotenoids were approximately two times higher under dark conditions compared to the levels under light conditions (Figure 5C). Interestingly, transcript levels of genes encoding antioxidant metabolizing enzymes, such as glutathione peroxidase (GPX), catalase (katE), and superoxide dismutase (sodC), were elevated by more than two-fold under dark conditions (Figure 5D). Higher transcript levels of $O x y R$ gene, which functions as an $\mathrm{H}_{2} \mathrm{O}_{2}$-inducible transcriptional activator, were also induced under dark conditions. These results indicate that ROS levels were elevated under light conditions due to decreased antioxidant activity.

Altogether, we have derived optimal growth conditions, including light, culturing time, temperature, and medium composition, for cell growth and PHB production in $R$. sphaeroides. It is envisaged that alterations of growth conditions cause changes in ROS levels. Consequently, ROS is expected to have a huge influence on cell growth and PHB production, such as the effects of light.

\section{Discussion}

In this study, we carried out optimization of culture conditions, such as light presence, oxygen existence, harvesting time, temperature, and composition of medium, for cell growth and PHB production in Rhodobacter sphaeroides. We found that PHB content is the highest under dark-aerobic conditions. In dark-aerobic conditions, the cell growth is promoted with the application of oxygen as a terminal electron acceptor and succinic acid as a carbon and energy source. The photo-sensitive cyclic electron transfer pathway is shut down under the dark conditions due to the termination of the photo-oxidation in the reaction center (RC) [45]. Consequently, the reducing equivalents are 
accumulated within the cytoplasmic membrane, causing greater production of PHB as an electron and carbon sink. We observed maximum cell growth as well as PHB accumulation at $48 \mathrm{~h}$. After $48 \mathrm{~h}$, the cell vitality reduced, and the PHB contents decreased by almost $50 \%$ compared to the level at $48 \mathrm{~h}$. Initiation of PHB degradation when the cells reached the stationary phase was reported previously, confirming the importance of harvesting time on PHB production [3]. Similar to our results on the effects of temperature, $\mathrm{PHB}$ synthesis decreased at higher and lower temperatures than $30^{\circ} \mathrm{C}$ in Bacillus subtilis, which is likely caused by the decline of PHB synthetic enzyme activity [46]. PHB production is significantly affected by nitrogen availability when the amount of carbon remains the same and is not required under nutrient-rich conditions [5,47], supporting our data on the effects of the carbon/nitrogen ratio in the medium. Carbon and nitrogen sources are also very closely related to PHB production. In Rhodobacter, it has been reported that organic acids and inorganic nitrogen sources produce better PHB than sugar and organic nitrogen sources, respectively [17,48]. Adding medium optimization to our optimal PHB production conditions will allow us to achieve higher PHB production.

We examined the expression patterns of four genes, $P h a A, P h a B, P h a C$, and PhaZ, involved in the biosynthesis and metabolism of PHB in R. sphaeroides. The overall transcript levels of PhaA and PhaB genes were similar under diverse experimental conditions, because PhaA and PhaB genes are located in the same operon, while the PhaC and PhaZ genes are located in a different operon [19]. The PhaA gene is important to initiate PHB production by acetyl-CoA condensation, and the PhaB gene is the most critical genetic component for PHB productivity [49]. Therefore, expression levels of $P h a A$ and PhaB genes indicated a strong correlation with PHB production, whereas those of $P h a C$ and PhaZ genes were independent relatively. The PhaZ gene, which mediates PHB depolymerization, is downregulated during the active growth phase by PhaR, a regulator protein of phaZCPR operon [5]. Recent studies revealed that disruption of the PhaZ gene and overexpression of the PhaA, PhaB, and PhaC genes elevated PHB production in R. sphaeroides [18]. Moreover, PHB biosynthetic enzymes, including PhaC, which is the limiting step for PHB production in $R$. sphaeroides, altered their activities very easily in response to changes in the external environment $[18,50]$. It is expected that PHB production will be further enhanced through combination with optimization for the expression of PHB biosynthesis-related genes and growth conditions.

Since R. sphaeroides has a versatile metabolism, modification of the substrate instead of succinic acid in the medium can be a solution to improve the economics of PHB production. In terms of bioremediation, municipal and industrial organic waste, including food waste and sludge, are good alternatives. $\mathrm{CO}_{2}$ will be utilized as the main carbon source for PHB production in the future, because $R$. sphaeroides also has the ability to utilize $\mathrm{CO}_{2}$. Furthermore, to compensate for the physical properties of $\mathrm{PHB}$, including brittleness and poor processability, it is possible to produce copolymers, such as poly(3-hydroxybutyrate-co-3-hydroxyvalerate) (PHBV), by utilizing long-chain carbohydrates such as propionic acid as a carbon source [51]. In some cases, interactions between $R$. sphaeroides and other microorganisms lead to better production results. When the three different types of $R$. sphaeroides were mixed, they showed higher hydrogen yield and specific production rate than each pure culture [52]. Through co-culture with Clostridium butyricum, acetic acid produced by C. butyricum was used as a substrate to increase the rate of hydrogen production [53]. In this way, mixed microorganisms can create synergy that balances energy and substances by constructing various metabolic pathways through interdependent relationships.

Air and light cause oxidative stress, such as cell death, growth retardation, and alteration of metabolism, in bacteria. Our results also indicate that light leads to changes in intracellular ROS levels and antioxidant activities such as peroxidase activities and carotenoid accumulation. In the presence of carotenoids, the cells can be partially protected from oxidative damage. The carotenoid-deficient mutants were more sensitive to ROS compared to wild-type R. sphaeroides [27], indicating that carotenoids act as an antioxidant. These observations indicate that PHB production is strongly influenced by ROS. Whereas the concentration of $\mathrm{H}_{2} \mathrm{O}_{2}$ was slightly higher under light conditions than under dark conditions, PHB contents were higher under dark conditions compared to light 
conditions in R. sphaeroides. In Caulobacter crescentus, $\mathrm{H}_{2} \mathrm{O}_{2}$-induced gene expression involved in $\mathrm{PHB}$ depolymerization [54]. Methyl-esterified 3-hydroxybutyrate (ME-3HB) oligomers, synthesized by PHB depolymerization, protect the bacteria cells from ROS due to their ROS scavenging activity [55]. $R$. sphaeroides is also known to produce PHB well, and thus, it will be very interesting to study the mechanism of ROS regulation by these oligomers in the future.

Furthermore, R. sphaeroides has diverse biosynthetic pathway and is capable of growth under various environments, such as light/dark, aerobic/anaerobic, and autotrophic/heterotrophic conditions. This implies that ROS generated by light, air, and high/low temperatures has a critical impact on intracellular metabolism. These features suggest that $R$. sphaeroides is a good model system to study ROS signaling adaptation to environmental changes and mediation of biochemical production.

Author Contributions: Conceptualization, S.Y.L. and S.L.; formal analysis, Y.R.L., H.N.F., M.-S.K., and M.M.; data curation, Y.R.L., H.N.F., S.Y.L., W.-H.L., and S.L.; writing-original draft preparation, Y.R.L., H.N.F., S.Y.L., and S.L.; writing-review and editing, W.-H.L., J.-S.L., and S.L.; funding acquisition, M.-S.K. and J.-S.L. All authors have read and agreed to the published version of the manuscript.

Funding: This research was conducted under the framework of the Research and Development Program of the Korea Institute of Energy Research (KIER-C0-2424); and the C1 Gas Refinery Program through the National Research Foundation of Korea (NRF) funded by the Ministry of Science and ICT (NRF-2017M3D3A1A01036923), South Korea.

Conflicts of Interest: The authors declare no conflict of interest. The funders had no role in the design of the study; in the collection, analyses, or interpretation of data; in the writing of the manuscript, or in the decision to publish the results.

\section{References}

1. Luengo, J.M.; García, B.; Sandoval, A.; Naharro, G.; Olivera, E.R. Bioplastics from microorganisms. Curr. Opin. Microbiol. 2003, 6, 251-260. [CrossRef]

2. Reddy, C.S.K.; Ghai, R.; Rashmi; Kalia, V.C. Polyhydroxyalkanoates: An overview. Bioresour. Technol. 2003, 87, 137-146. [CrossRef]

3. Grothe, E.; Moo-Young, M.; Chisti, Y. Fermentation optimization for the production of poly( $\beta$-hydroxybutyric acid) microbial thermoplastic. Enzym. Microb. Technol. 1999, 25, 132-141. [CrossRef]

4. García-Torreiro, M.; Lu-Chau, T.A.; Lema, J.M. Effect of nitrogen and/or oxygen concentration on poly(3-hydroxybutyrate) accumulation by Halomonas boliviensis. Bioprocess Biosyst. Eng. 2016, 39, 1365-1374. [CrossRef]

5. Chou, M.E.; Chang, W.T.; Chang, Y.C.; Yang, M.K. Expression of four pha genes involved in poly- $\beta$-hydroxybutyrate production and accumulation in Rhodobacter sphaeroides FJ1. Mol. Genet. Genom. 2009, 282, 97-106. [CrossRef]

6. Steinbüchel, A.; Hustede, E.; Liebergesell, M.; Pieper, U.; Timm, A.; Valentin, H. Molecular basis for biosynthesis and accumulation of polyhydroxyalkanoic acids in bacteria. FEMS Microbiol. Rev. 1992, 103, 217-230. [CrossRef]

7. Lenz, R.W.; Marchessault, R.H. Bacterial polyesters: Biosynthesis, biodegradable plastics and biotechnology. Biomacromolecules 2005, 6, 1-8. [CrossRef]

8. Mahishi, L.H.; Rawal, S.K. Effect of amino acid smentation on the synthesis of poly(3-hydroxybutyrate) by recombinant $\mathrm{pha}_{\mathrm{Sa}}{ }^{+}$Escherichia coli. World J. Microbiol. Biotechnol. 2002, 18, 805-810. [CrossRef]

9. Mahishi, L.H.; Tripathi, G.; Rawal, S.K. Poly(3-hydroxybutyrate) (PHB) synthesis by recombinant Escherichia coli harbouring Streptomyces aureofaciens PHB biosynthesis genes: Effect of various carbon and nitrogen sources. Microbiol. Res. 2003, 158, 19-27. [CrossRef]

10. Kang, D.K.; Lee, C.R.; Lee, S.H.; Bae, J.H.; Park, Y.K.; Rhee, Y.H.; Sung, B.H.; Sohn, J.H. Production of polyhydroxyalkanoates from sludge palm oil using Pseudomonas putida S12. J. Microbiol. Biotechnol. 2017, 27, 990-994. [CrossRef]

11. Song, J.H.; Jeon, C.O.; Choi, M.H.; Yoon, S.C.; Park, W. Polyhydroxyalkanoate (PHA) production using waste vegetable oil by Pseudomonas sp. Strain DR2. J. Microbiol. Biotechnol. 2008, 18, 1408-1415. [PubMed]

12. Khanna, S.; Srivastava, A.K. Statistical media optimization studies for growth and PHB production by Ralstonia eutropha. Process Biochem. 2005, 40, 2173-2182. [CrossRef] 
13. Riedel, S.L.; Jahns, S.; Koenig, S.; Bock, M.C.E.; Brigham, C.J.; Bader, J.; Stahl, U. Polyhydroxyalkanoates production with Ralstonia eutropha from low quality waste animal fats. J. Biotechnol. 2015, 214, 119-127. [CrossRef] [PubMed]

14. Revelles, O.; Beneroso, D.; Menéndez, J.A.; Arenillas, A.; García, J.L.; Prieto, M.A. Syngas obtained by microwave pyrolysis of household wastes as feedstock for polyhydroxyalkanoate production in Rhodospirillum rubrum. Microb. Biotechnol. 2017, 10, 1412-1417. [CrossRef]

15. Karmann, S.; Panke, S.; Zinn, M. Fed-batch cultivations of Rhodospirillum rubrum under multiple nutrient-limited growth conditions on syngas as a novel option to produce poly(3-hydroxybutyrate) (PHB). Front. Bioeng. Biotechnol. 2019, 7, 1-11. [CrossRef]

16. Brandl, H.; Gross, R.A.; Lenz, R.W.; Lloyd, R.; Fuller, R.C. The accumulation of poly(3-hydroxyalkanoates) in Rhodobacter sphaeroides. Arch. Microbiol. 1991, 155, 337-340. [CrossRef]

17. Sangkharak, K.; Prasertsan, P. Nutrient optimization for production of polyhydroxybutyrate from halotolerant photosynthetic bacteria cultivated under aerobic-dark condition. Electron. J. Biotechnol. 2008, 11, 3. [CrossRef]

18. Kobayashi, J.; Kondo, A. Disruption of poly (3-hydroxyalkanoate) depolymerase gene and overexpression of three poly (3-hydroxybutyrate) biosynthetic genes improve poly (3-hydroxybutyrate) production from nitrogen rich medium by Rhodobacter sphaeroides. Microb. Cell Fact. 2019, 18, 1-13. [CrossRef]

19. Yang, M.K.; Lin, Y.C.; Shen, C.H. Identification of two gene loci involved in poly-beta-hydroxybutyrate production in Rhodobacter sphaeroides FJ1. J. Microbiol. Immunol. Infect. 2006, 39, 18-27.

20. Chou, M.E.; Yang, M.K. Analyses of binding sequences of the PhaR protein of Rhodobacter sphaeroides FJ1. FEMS Microbiol. Lett. 2010, 302, 138-143. [CrossRef]

21. Zeilstra-Ryalls, J.H.; Kaplan, S. Oxygen intervention in the regulation of gene expression: The photosynthetic bacterial paradigm. Cell. Mol. Life Sci. 2004, 61, 417-436. [CrossRef] [PubMed]

22. Kaplan, S.; Eraso, J.; Roh, J.H. Interacting regulatory networks in the facultative photosynthetic bacterium, Rhodobacter sphaeroides 2.4.1. Biochem. Soc. Trans. 2005, 33, 51-55. [CrossRef] [PubMed]

23. Ziegelhoffer, E.C.; Donohue, T.J. Bacterial responses to photo-oxidative stress. Nat. Rev. Microbiol. 2009, 7, 856-863. [CrossRef] [PubMed]

24. Fu, H.; Yuan, J.; Gao, H. Microbial oxidative stress response: Novel insights from environmental facultative anaerobic bacteria. Arch. Biochem. Biophys. 2015, 584, 28-35. [CrossRef] [PubMed]

25. Abee, T.; Wouters, J.A. Microbial stress response in minimal processing. Int. J. Food Microbiol. 1999, 50, 65-91. [CrossRef]

26. Licht, M.K.; Nuss, A.M.; Volk, M.; Konzer, A.; Beckstette, M.; Berghoff, B.A.; Klug, G. Adaptation to photooxidative stress: Common and special strategies of the alphaproteobacteria Rhodobacter sphaeroides and Rhodobacter capsulatus. Microorganisms 2020, 8, 283. [CrossRef]

27. Glaeser, J.; Klug, G. Photo-oxidative stress in Rhodobacter sphaeroides: Protective role of carotenoids and expression of selected genes. Microbiology 2005, 151, 1927-1938. [CrossRef]

28. Zeller, T.; Klug, G. Detoxification of hydrogen peroxide and expression of catalase genes in Rhodobacter. Microbiology 2004, 150, 3451-3462. [CrossRef]

29. Kho, D.H.; Yoo, S.B.; Kim, J.S.; Kim, E.J.; Lee, J.K. Characterization of Cu- and Zn-containing superoxide dismutase of Rhodobacter sphaeroides. FEMS Microbiol. Lett. 2004, 234, 261-267. [CrossRef]

30. Uchoa, A.F.; Knox, P.P.; Turchielle, R.; Seifullina, N.K.; Baptista, M.S. Singlet oxygen generation in the reaction centers of Rhodobacter sphaeroides. Eur. Biophys. J. 2008, 37, 843-850. [CrossRef]

31. Zeller, T.; Mraheil, M.A.; Moskvin, O.V.; Li, K.; Gomelsky, M.; Klug, G. Regulation of hydrogen peroxide-dependent gene expression in Rhodobacter sphaeroides: Regulatory functions of QxyR. J. Bacteriol. 2007, 189, 3784-3792. [CrossRef] [PubMed]

32. Sistrom, W.R. The kinetics of the synthesis of photopigments in Rhodopseudomonas sphaeroides. J. Gen. Microbiol. 1962, 28, 607-616. [CrossRef] [PubMed]

33. Lee, S.; Lee, H.J.; Jung, J.H.; Park, C.M. The Arabidopsis thaliana RNA-binding protein FCA regulates thermotolerance by modulating the detoxification of reactive oxygen species. New Phytol. 2015, 205, 555-569. [CrossRef] [PubMed]

34. Lee, S.; Kim, S.G.; Park, C.M. Salicylic acid promotes seed germination under high salinity by modulating antioxidant activity in Arabidopsis. New Phytol. 2010, 188, 626-637. [CrossRef] [PubMed] 
35. Wang, X.; Modak, H.V.; Tabita, F.R. Photolithoautotrophic growth and control of $\mathrm{CO}_{2}$ fixation in Rhodobacter sphaeroides and Rhodospirillum rubrum in the absence of ribulose bisphosphate carboxylase-oxygenase. J. Bacteriol. 1993, 175, 7109-7114. [CrossRef]

36. Kim, M.S.; Kim, D.H.; Cha, J. Culture conditions affecting $\mathrm{H}_{2}$ production by phototrophic bacterium Rhodobacter sphaeroides KD131. Int. J. Hydrog. Energy 2012, 37, 14055-14061. [CrossRef]

37. Kim, M.S.; Kim, D.H.; Cha, J.; Lee, J.K. Effect of carbon and nitrogen sources on photo-fermentative $\mathrm{H}_{2}$ production associated with nitrogenase, uptake hydrogenase activity, and $\mathrm{PHB}$ accumulation in Rhodobacter sphaeroides KD131. Bioresour. Technol. 2012, 116, 179-183. [CrossRef]

38. Kemavongse, K.; Prasertsan, P.; Upaichit, A.; Methacanon, P. Poly- $\beta$-hydroxyalkanoate production by halotolerant Rhodobacter sphaeroides U7. World J. Microbiol. Biotechnol. 2008, 24, 2073-2085. [CrossRef]

39. Sangkharak, K.; Prasertsan, P. Optimization of polyhydroxybutyrate production from a wild type and two mutant strains of Rhodobacter sphaeroides using statistical method. J. Biotechnol. 2007, 132, 331-340. [CrossRef]

40. McEwan, A.G. Photosynthetic electron transport and anaerobic metabolism in purple non-sulfur phototrophic bacteria. Antonie Leeuwenhoek 1994, 66, 151-164. [CrossRef]

41. Morita, R.Y. Bioavailability of energy and its relationship to growth and starvation survival in nature. Can. J. Microbiol. 1988, 34, 436-441. [CrossRef]

42. Mullineaux, P.M.; Exposito-Rodriguez, M.; Laissue, P.P.; Smirnoff, N. ROS-dependent signalling pathways in plants and algae exposed to high light: Comparisons with other eukaryotes. Free Radic. Biol. Med. 2018, 122, 52-64. [CrossRef]

43. Nantapong, N.; Murata, R.; Trakulnaleamsai, S.; Kataoka, N.; Yakushi, T.; Matsushita, K. The effect of reactive oxygen species (ROS) and ROS-scavenging enzymes, superoxide dismutase and catalase, on the thermotolerant ability of Corynebacterium glutamicum. Appl. Microbiol. Biotechnol. 2019, 103, 5355-5366. [CrossRef] [PubMed]

44. Aguirre, J.; Ríos-Momberg, M.; Hewitt, D.; Hansberg, W. Reactive oxygen species and development in microbial eukaryotes. Trends Microbiol. 2005, 13, 111-118. [CrossRef]

45. Wong, M.T.; Cheng, D.; Wang, R.; Hsing, I.M. Modifying the endogenous electron fluxes of Rhodobacter sphaeroides 2.4.1 for improved electricity generation. Enzym. Microb. Technol. 2016, 86, 45-51. [CrossRef]

46. Tamdoğan, N.; Sidal, U. Investigation of poly- $\beta$-hydroxybutyrate (PHB) production by Bacillus subtilis ATCC 6633 under different conditions. Kafkas Univ. Vet. Fak. Derg. 2011, 17, 173-176. [CrossRef]

47. Cui, Y.W.; Shi, Y.P.; Gong, X.Y. Effects of $\mathrm{C} / \mathrm{N}$ in the substrate on the simultaneous production of polyhydroxyalkanoates and extracellular polymeric substances by Haloferax mediterranei via kinetic model analysis. RSC Adv. 2017, 7, 18953-18961. [CrossRef]

48. Merugu, R.; Rao, A.S. Optimization of polyhydroxybutyrate production by two phototrophic bacteria Rhodobacter capsulatus KU002 and Rhodopseudomonas palustris KU003. J. Chem. Pharm. Res. 2015, 7, 260-264.

49. Jin, H.; Nikolau, B.J. Evaluating PHA productivity of bioengineered Rhodosprillum rubrum. PLoS ONE 2014, 9, e96621. [CrossRef]

50. Matsumoto, K.; Tobitani, K.; Aoki, S.; Song, Y.; Ooi, T.; Taguchi, S. Improved production of poly(lactic acid)-like polyester based on metabolite analysis to address the rate-limiting step. AMB Express 2014, 4, 1-5. [CrossRef]

51. Garcia-Gonzalez, L.; De Wever, H. Acetic acid as an indirect sink of $\mathrm{CO}_{2}$ for the synthesis of polyhydroxyalkanoates (PHA): Comparison with PHA production processes directly using $\mathrm{CO}_{2}$ as feedstock. Appl. Sci. 2018, 8, 1416. [CrossRef]

52. Argun, H.; Kargi, F.; Kapdan, I.K. Light fermentation of dark fermentation effluent for bio-hydrogen production by different Rhodobacter species at different initial volatile fatty acid (VFA) concentrations. Int. J. Hydrog. Energy 2008, 33, 7405-7412. [CrossRef]

53. Fang, H.H.P.; Zhu, H.; Zhang, T. Phototrophic hydrogen production from glucose by pure and co-cultures of Clostridium butyricum and Rhodobacter sphaeroides. Int. J. Hydrog. Energy 2006, 31, 2223-2230. [CrossRef]

54. Silva, L.G.; Lorenzetti, A.P.R.; Ribeiro, R.A.; Alves, I.R.; Leaden, L.; Galhardo, R.S.; Koide, T.; Marques, M.V. OxyR and the hydrogen peroxide stress response in Caulobacter crescentus. Gene 2019, 700, 70-84. [CrossRef] 
55. Koskimäki, J.J.; Kajula, M.; Hokkanen, J.; Ihantola, E.L.; Kim, J.H.; Hautajärvi, H.; Hankala, E.; Suokas, M.; Pohjanen, J.; Podolich, O.; et al. Methyl-esterified 3-hydroxybutyrate oligomers protect bacteria from hydroxyl radicals. Nat. Chem. Biol. 2016, 12, 332-338. [CrossRef]

Publisher's Note: MDPI stays neutral with regard to jurisdictional claims in published maps and institutional affiliations.

(C) 2020 by the authors. Licensee MDPI, Basel, Switzerland. This article is an open access article distributed under the terms and conditions of the Creative Commons Attribution (CC BY) license (http://creativecommons.org/licenses/by/4.0/). 